\title{
ROBERT HAROLD BLYTHE
}

Every institution of any substance and importance has its story of ups and downs, in which is chronicled at least one major disaster, which seems at the time to shatter not only its fortunes, but also the spirits of those who are responsible for its work and welfare.

The Fellowship of Postgraduate Medicine has had to record the loss of many distinguished servants, mostly members of the medical profession whose names were a household word throughout the country. The sudden and unexpected death of our Business Manager has come to us all as a shattering blow. Mr. Blythe came to us in 194I, at a time when the Fellowship was hard put to it to maintain its equilibrium, and it is no exaggeration to say that its continued good fortunes and the increase in the prestige and success of its two Journals were largely due to his initiative and to the loyal and untiring energy which he devoted to its interests. To say this is the least we can do in justice to his memory; to express what we shall feel at the loss of one who had become to all of us on the Executive Committee and Editorial Board a very dear personal friend is far more difficult. Like most high-souled individuals to whom their work was a real vocation, he was gentle, modest and unassuming. His interest in our future well-being was very real, and he gave us of his best to the utmost. Those who had to work with him can never forget his untiring energy, his tact, and above all his extreme patience and forbearance, often in circumstances in which others, more materially minded, would have thrown up the sponge and left us in the lurch.

Blythe was a first-class man of business, full of knowledge, experience and initiative. With these qualities were combined a devotion and loyalty to his employers which are not conspicuous in these days. There is little doubt that the constant output of mental and physical energy which he expended, regardless of himself, in the discharge of his obligations were partly responsible for his sudden and untimely death, and so we bid him farewell with a deep sense of gratitude and in the knowledge that 'greater love hath no man than this that a man lay down his life for his friends.'

Maurice Davidson

\section{E D I T O R I A L}

\section{Weighing the Odds}

Weighing the odds is a process familiar to all of us from our earliest years. Probably the first such situation to be faced consciously for most of us concerned food and was a matter of quantity. Later we had to measure such risks as those involved in a catapult after a summary, but obviously unreasonable, confiscation; were they merely serious or catastrophic? Obviously such questions could only be settled by experiment, and experience was apt to be painful. Thence we passed on to slightly more serious matters involving others as well as ourselves. If we won the toss should we bat first, or should we put them in and hope for some quick wickets?

Generally speaking, however, throughout our school days experiment was a healthy line of approach to most problems. The penalties of losing were not too high and, in any case, involved nobody but oneself. Much depended on personalities and in these matters your schoolboy can be a first-class psychologist.

Having surmounted the difficulties of youth in which a slowly increasing experience came to our 
aid, we then came to the turning point of choosing a career. Here experience deserted us and we had to rely on impressions, on hearsay and on the example and reactions of others. For some this decision was easy. For the boy who has spent all his spare time tinkering happily with engines or for the girl with musical talent, the question is resolved simply into one of the means rather than of the end. For the many without such pronounced vocations, however, choosing a career is a formidable problem in which the deciding factor is often the influence of some other person. Had Osler not come under the influence of so profound a naturelover as the warden of his school in Weston, Ontario, the Rev. Johnson, and learned from him the thrill of adventure in finding, observing and classifying natural history specimens, he would almost certainly have followed in his father's footsteps as a minister. Instead, at the age of 18 he had already written his first scientific paper, on the subject of the Diatomaceae, and had started on the career which was to have so far-reaching and enriching an influence on our profession.

Later comes the paramount question of choosing a wife or a husband. Here again experience is limited, example may well be fallacious and experiment is unquestionably a bad preceptor. None the less it involves a decision which to many is one of the easiest, though perhaps not initiated or settled nearly so entirely by the one party as might be thought.

In business matters the successful firm is undoubtedly the one which has adopted the most progressive policy, has opened new factories, taken over new premises, made the biggest advertising outlay and has weighed the odds correctly.

To some individuals decisions come easily, as if by instinct; moreover, having taken their decision, the possibility of error seems not to cross their minds. Of such metal are great leaders. Napoleon hurries back from Russia having lost half a million men with no thought save for the future. To others the excitement of weighing the odds is attractive and, by frequent repetition, becomes almost second nature to them. For the professional punter to be out of reach of the racing results is unthinkable; but success with him is by no means a matter of following his fancy. That is for the amateur. For him it is a matter of following the form from every angle, from personal observation of all the relevant details and from hearsay (though rarely, we understand, from the horse's mouth). By these means do our leading bookmakers never owe.

To others, however, the weighing of odds is an onerous and painful duty, undertaken unwillingly and concluded falteringly. The man who throughout his working days remains a plumber's mate is in many ways to be envied. Watching the boss work always had a fascination whilst, if things go badly, the mate may have hard words to bear but the fault is not his. Admittedly he misses the thrill of deciding which system of drainage shall be installed, but many of us are not unhappy to avoid this responsibility.

In the field of medicine there can be no question that experience is by far the most important factor in weighing the odds; experience in knowing the likely course of the disease untreated; in knowing the advantages and disadvantages of the possible lines of treatment; in understanding the patient's point of view and in estimating his reactions. By keeping abreast of the literature we are, moreover, able to add to our own the collected experience of others. In the treatment of gastric and duodenal ulceration, for the uncomplicated case there is little doubt that the odds are weighted heavily in favour of medical measures as the first line of treatment. With cure as the objective, experience has shown the futility of half-measures in this matter. Palliation is surely the best way to perpetuate the condition. Rarely is an ulcer of the leg healed in three weeks, much less so one in a constantly active and secreting stomach or duodenum. Medical treatment should therefore be thorough, cure being constantly kept in mind as its goal. The milk drip, as recently ably advocated by Clark (1950, Lancet, I, 435), would appear on physiological grounds, and has been proved by experience to be a valuable means of therapy in this connection. Even with it, however, the time factor remains of paramount importance though at present much limited by bed shortage.

With recurrence after full medical treatment and with the onset of complications, weighing the odds becomes a more onerous duty. As the 
surgery of these conditions has become safer, treatment has swung more and more towards it for the otherwise fit patient.

For perforation, those surgeons who, from time to time, have tried medical measures have invariably seen the error of their ways. With obstructive symptoms, however mild, the factor of ?nevitability is introduced. However effective medical treatment may be, it is unable to relax a relentlessly tightening stricture. If operation is delayed it will be necessary in perhaps 12 months, and for those months the patient is at least a semiinvalid, in constant danger, and probably fear, of relapse. Medical measures are here in our view largely a matter of temporizing.

In cases of gastric and duodenal haemorrhage, weighing the odds has for all time given medical men some of their most anxious and sleepless hours. How strongly we supported the morphiastarvation regime and with what concern we read that Meulengracht was actually daring to feed such cases. His reason for doing so was that he had watched the agony of a patient dying under the old regime with parotitis.

Gradually more liberal methods were adopted, both in feeding and in transfusion. Gradually too it was shown that surgery, invoked early, could be both life-saving and curative. Gordon-Taylor in this country and Finsterer in Vienna were pioneers of the way. Finsterer has now reduced his indications for treatment in the condition to the simple rules quoted in the leading article of this issue, in which Tanner and Desmond describe their very extensive experience both before and since their adoption of these rules. Their work and the results they have achieved by superb technique are of outstanding importance and represent a milestone in the advance of treatment. Physicians and surgeons alike will be grateful to them for this added experience and reasoned thinking now to hand in weighing the odds in this most anxious and urgent of problems.

\section{ANNOTATION}

\section{The Medical Research Council}

During the last thirty years the Medical Research Council has become such an integral part of the medical life of this country and Commonwealth that its many-sided activities are in danger of being taken too much for granted. The opening of the new wing of the Council's Research Institution at Mill Hill by H.M. The King on May 5 affords an opportunity for a brief survey of the origin of the Council and of the contributions which it makes to the work of the medical profession and to the well-being of the community.

The M.R.C. traces its ancestral development to the Medical Research Committee, founded in 191 3 to administer funds for research into tuberculosis and other diseases under the National Health Insurance Scheme. It achieved a high reputation during the First World War and in
I920, after the establishment of the Ministry of Health, it assumed its present title and became reconstituted under the Statutory authority of a new Committee of the Privy Council for Medical Research. This new Committee is under the chairmanship of the Lord President of the Council with the Minister of Health as vice-chairman, and on it are represented those Government departments concerned with matters of public health in the United Kingdom, Commonwealth and Empire; the Secretary is ex-officio the Secretary of the Medical Research Council. The Medical Research Council was granted a Royal Charter of Incorporation, its funds are provided by the Treasury in the form of a grant-in-aid approved annually by Parliament, while the Lord President of the Council is responsible to Parliament for its work. It has a membership of twelve, three lay and nine scientific; of the lay members one must come from the House of Lords and one from the Commons, while the scientific members are drawn from different branches of the profession 